Chapman University

Chapman University Digital Commons

$10-21-2019$

\title{
Growing the Revolutionary Intellectual, Creating the Counterpublic Sphere
}

Peter McLaren

Chapman University, mclaren@chapman.edu

Lilia D. Monzó

Chapman University, monzo@chapman.edu

Follow this and additional works at: https://digitalcommons.chapman.edu/education_books

Part of the Curriculum and Social Inquiry Commons

\section{Recommended Citation}

McLaren, P., \& Monzó, L. D. (2019). Growing the revolutionary intellectual, creating the counterpublic sphere. In P. Leavy (Ed.), The Oxford Handbook of Methods for Public Scholarship (pp. 669-700). Oxford University Press.

This Book is brought to you for free and open access by the Attallah College of Educational Studies at Chapman University Digital Commons. It has been accepted for inclusion in Education Faculty Books and Book Chapters by an authorized administrator of Chapman University Digital Commons. For more information, please contact laughtin@chapman.edu. 


\section{OXFORD \\ UNIVERSITY PRESS}

Oxford University Press is a department of the University of Oxford.

It furthers the University's objective of excellence in research, scholarship, and education by publishing worldwide. Oxford is a registered trade mark of

Oxford University Press in the UK and certain other countries.

Published in the United States of America by Oxford University Prèss 198 Madison Avenue, New York, NY 10016, United States of America.

(c) Oxford University Press 2019

All rights reserved. No part of this publication may be reproduced, stored in a retrieval system, or transmitted, in any form or by any means, without the prior permission in writing of Oxford University Press, or as expressly permitted by law, by license, or under terms agreed with the appropriate reproduction rights organization. Inquiries concerning reproduction outside the scope of the above should be sent to the Rights Department, Oxford University Press, at the address above.

You must not circulate this work in any other form and you must impose this same condition on any acquirer.

Library of Congress Cataloging-in-Publication Data Names: editor. Leavy, Patricia, 1975-

Title: The Oxford handbook of methods for public scholarship / edited by Patricia Leavy.

Other titles: Handbook of methods for public scholarship Description: New York, NY, United States of America : Oxford University Press, 2019. | Includes bibliographical references.

Identifiers: LCCN 2018048556 | ISBN 9780190274481 (hardcover : alk, paper)

Subjects: LCSH: Learning and scholarship-Social aspects. |

Research-Methodology. | Research-Social aspects.

Classification: LCC AZ362 .084 2019 | DDC 001.2-dc23

LC record available at https://lccn.loc.gov/2018048556

135798642

Printed by Marquis, Canada 


\section{CHAPTER 29}

\section{GROW ING THE \\ REVOLUTIONARY \\ IN T E L L EC T UA L, \\ CREATING THE \\ COUNTERPUBLIC SPHERE}

PETER MCLAREN AND LILIA D. MONZÓ

In these dangerous times of corporate-led globalization, endemic racism, the dehumanization of women, nationalist fervor, pending environmental disaster, corrupted power and moral decay, government surveillance and the eclipse of personal freedoms, exacerbated individualism and a global strongman politics that may lead us toward apocalyptic doom, it becomes our responsibility as public intellectuals to pose urgent questions to our constituencies that are often considered too discomfiting or too threatening for inclusion in public forums and that must be seasoned with conventional applications of political domestication in order to be considered for inclusion in contemporary debates.

Society is in desperate need of a new paradigm of public intellectual (or, in our account, an out-of-fashion exemplar repurposed for our new age of barbarism) that refuses to accept the limit situations imposed by the transnational capitalist state, a paradigm designed to encourage the intellectual to break free from the multiperspectival approaches to theory most often associated with postmodern free-market intellectuals, approaches that continue to deflect attention away from the pervasive contradictions immanent in capitalist social relations and from the totalizing effects of alienation and immiseration that globalized capitalism has wreaked upon every aspect of contemporary existence in capitalist societies. Fischman and McLaren (2005) describe the relationship between cultural struggle and the capitalist state as understood by the postmodern intellectual as follows:

[G]roups and classes exist in a shifting and mediated relationship, in a structured field of complex relations and ideological forces stitched together out of social 
fragments and privileging hierarchies, in structured asymmetries of power, in contending vectors of influence, and in emergent, contingent alliances. When one examines ideology, one must not look for smooth lines of articulation or a set of seamless canonical ideas, but rather a regime of culture existing as a palimpsest of emergent and residual discourses. (p. 430)

What is problematic in this description is the elision of capitalist social relations of production as a fundamental feature in creating the conditions of possibility for so many of these vectors, forces, and lines of articulation. Seriously neglected is the axial social contradiction between capital and labor. What is emphasized are changes in the mode of accumulation, exchange, and circulation of capital as if these are somehow superordinate over material relations of exploitation linked to production (i.e., to the extraction of surplus labor from workers who have nothing else to sell but their capacity to labor, their labor power). For this reason, we argue that rehabilitating the role of the revolutionary intellectual (examples could include Paulo Freire, Karl Marx, Rosa Luxemburg, Emma Goldman, and Che Guevara) constitutes an urgent challenge for those who wish to defend and deepen the public sphere currently under siege by the scourge of authoritarian populism and increasingly colonized by the ideological imperatives of the transnational capitalist class. Hence the urgency of posing an unvarnished challenge to current and contemporary iterations of intellectual discourse that have in this historical moment become overburdened by the inevitability of global capitalism and overpopulated by resignation and despair.

The intellectual we are describing must be willing to engage in the development of a collective social imaginary grounded in an alternative to capitalist relations of exploitation and alienation. This requires no less than an epitomizing and panoramic exposition of the congealed suffering of the popular classes and of the racism and misogyny that plagues the contemporary transnational capitalist state (Robinson, 2016). The primary setting for our discussion is the United States-the epicenter of disaster capitalismwhere the most impoverished communities of color that are made expendable and left to fester in hunger and fear and targeted for prison slave labor have been likened to the "third world" (Monzó, McLaren, \& Rodriguez, 2016).

Here we seek to illuminate some important nuances and articulations surrounding the challenges that face us as dissident intellectuals at this particular historical conjuncture and to explore ways in which the public intellectual can be reconceptualized and revitalized in revolutionary terms. This fits well with our goal for this essay-which intends to serve as a countervailing riposte to the role of the free-market intellectual and to insist on a materialist and indigenist recentering of the role of the intellectual in today's social order.

The civil rights movements of the 1960 s brought about important gains in the struggles fought by women, people of color, and the LGBTQIA community, and these struggles have continued to gain popular support among many progressives who at one time may have been only concerned with their own single-issue struggles. In the 1960s, organized activism and intellectuals as diverse as Martin Luther King, Jr., Harvey 
Milk, Germaine Greer, Malcolm X, Gore Vidal, and Noam Chomsky succeeded in appealing to the public's sense of justice and helped them to become more sensitive to the pain of poverty, of racism, and of being treated as subhuman peoples. Or so we thought.

The Trump presidential win, amidst xenophobic and misogynist rhetoric and stentorian pronouncements about the need to build a "wall," made clear the level of vulnerability felt by Americans in times of economic crisis and their willingness to reverse the epoch-making gains of the civil rights era if it meant economic protection for themselves and their families (Tankersley, 2016). It also strongly suggested that the worldview that brought us a Trump victory was scaffolded by an argumentum ad cruneman -that Trump must be correct on the economic issues since he is a billionaire. Many will argue that their vote for Trump was not motivated by racism but by a need for "political change," for economic growth, and for the importance of White working-class voices being "heard" (Tankersley, 2016). This is no doubt an important point and reminds us that although class and race are highly aligned, there exists a significantly large White working class who continue to suffer the dehumanizing effects of economic deprivation and lack of opportunity that are staples of capitalist social relations.

Nevertheless, the fact that so many people remained silent in the face of the familiar fear tactics used to accompany the stereotyping of Black men, Mexican and other Latinx communities, and Muslim peoples reveals a deep-seated reflex to blame racialized Others for existing social problems. That so many Americans invested in the slogan "make America great again," which attributes "greatness" to unforgiveable moments in our history defined by slavery, Jim Crow laws, and White supremacy, serves as an index for an endemic historical amnesia among mainly white voters. That they could ignore the hate-spewing racialized rhetorics of a bloviating egomaniacal billionaire reveals the workings of what McLaren (2015) refers to as the "structural unconscious"-a motivated forgetfulness surrounding American narratives of genocide (against indigenous peoples, African slaves, and the hundreds of thousands murdered in imperialist wars), narratives so burnished by lost time that we have become blinded to our own 'complacency.

In retrospect, the Trump win should not have come as a surprise. Despite significant gains in race relations made since the 196os, the Trump win reminds us that racism will likely always serve a significant purpose in capitalist value production-to divide the working class and diminish the potential for class struggle. During times of economic crises, when we would think the working class would unite against the capitalist class, we find instead that racism can be deployed as an effective tool to circumvent any tendency toward class solidarity. Marx first recognized this over a century ago when England's working classes aligned themselves to the capitalist class against their own class interests rather than side with the working class Fenians of Ireland (at the time perceived as an ethnic minority). Marx discussed this in a letter dated April 1870:

Every industrial and commercial center in England now possesses a working class divided into two camps, English proletarians and Irish proletarians. The English worker hates the Irish worker as a competitor who lowers his standard of life... He 
regards himself as a member of the ruling nation, and consequently, he becomes a tool of the English aristocrats and capitalists against Ireland, thus strengthening their domination over himself. He cherishes religious, social, and national prejudices against the Irish worker. His attitude towards him is much the same as that of the "poor whites" to the Negroes in the former slave states of the U.S.A. (para. 12)

This antagonism is artificially kept alive and intensified by the press, the pulpit, the comic papers, in short by all the means at the disposal of the ruling classes. This antagonism is the secret of the impotence of the English working class, despite its organization. It is the secret by which the capitalist class maintains its power. And the latter is quite aware of this. (para.13)

Racism is, thusly, so endemic to capitalist relations that it was easily brought to the surface via the fear tactics and violent ravings instigated by Trump, with the aid of the corporate media.

If we can attribute one good outcome to the Trump presidency so far, it is that public protest and popular interest in politics has risen dramatically as evidenced through growing participation in marches, teach-ins, and town hall meetings. In the wake of an increase in hate crimes we can also take note and comfort in the fact that there are many White allies in our midst willing to stand shoulder to shoulder with people of coloragainst racism, against misogyny, in support of undocumented workers and other Latinx peoples, in a spirited defense of Muslims and LGBTQIA communities, and in solidarity with indigenous peoples in their fight for sovereignty and with groups worldwide who are struggling to defend the rights of all peoples to live with freedom and dignity.

This historical moment is crucial for the defense of what remains of the democratic public sphere, a time in which the public intellectual must remain undaunted, committed to reenter the public sphere with new critical arguments against the status quo, honest accounts of real human suffering at the hands of capital, and fortified by a renewed capacity to offer a radical vision for a better humanity. Even under the gilded gavel of a capitalist plutocracy, we cannot forget that each moment of our existence provides opportunities to awaken the public from an anesthetized existence-an insensibility and political torpor that has been self and socially produced through hyper-consumerism and self-medication, those twin sieves made available to us by the consumer marketplace for filtering our desires from our needs, and for opening the floodgates to a world of unending digital dream-catchers. The case we wish to make is that the revolutionary intellectual is once again effectively poised to make visible to the public the ideological gridlock that has made the American structural unconscious so evasive and difficult to identify and to reveal the treacherous silence of the ruling class surrounding U.S. crimes against humanity. Such an intellectual stands ready to debate the issues that affect both the public good and ethical codes by which we choose to live. The revolutionary public intellectual, then, ought to bring forward issues of great social, economic, and political importance to the public but to do so with a clear focus on moving the world toward a 
socially just and humane existence-one that is absent in its current corporate-based agenda. This is especially important for building a democracy, wherein people exercise some degree of choice in their support of political candidates and measures based on their grasp of and disposition toward particular issues that affect themselves, their communities, and broader publics. Gramsci (1971) saw democracy as essentially a dialectical movement between individual agency and structural location:

But democracy, by definition, cannot mean merely that an unskilled worker can become skilled. It must mean that every "citizen" can "govern" and that society places him, even if only abstractly, in a general condition to achieve this. Political democracy tends towards a coincidence of the rulers and the ruled (in the sense of government with the consent of the governed) ensuring for each non-ruler a free training in the skill and general technical preparation necessary to that end.

(pp. 40-41)

Unfortunately, today's public intellectuals who challenge the political, ideological, and corporate interests of main street, rarely gain the necessary public visibility to impact in any significant way various debates that should be a concern to all Americans (Noam Chomsky is one of the most obvious examples). Instead of appointing public intellectuals to discuss the issues, the corporate media complex hires "expert" commentators, often retired politicians or members of the military, to procure their "opinions" on political issues since these individuals will presumably adhere to the mainstream aesthetics of the collective imagination, never digging too deeply in their commentaries, and certainly never challenging fundamental economic inequalities, juridical asymmetries, or the special interests of their corporate capitalist cronies. These free-market intellectuals serve as predictable bookends to debates, and they function in the same manner as canned laughter in comedies - to provide ideological markers for when to laugh, smile, and nod your head and to make listeners feel uneasy and out of step if they don't respond accordingly to the social script. The ideological comfort zones embedded in the social contract are fundamentally safe under their middlebrow tutelage, despite the treacheries and abominations of the "masters of mankind," as Adam Smith called them. That the questions they raise and the answers they give support ruling ideas and prop up corporate interests should come as no surprise to readers of Marx, who gave world-historical significance to the following pronouncement:

The ideas of the ruling class are in every epoch the ruling ideas. The class that is the ruling material force of society, is at the same time its ruling intellectual force. The class that has the means of material production at its disposal has control at the same time over the means of mental production, so that thereby, generally speaking, the ideas of those who lack the means of mental production are subject to it. The ruling ideas are nothing more than the ideal expression of the dominant material relationships, the dominant material relationships grasped as ideas.

(cited in Robinson, 2016, p. 16) 
In what follows, we wish to make a distinction between the "free market" intellectual and the revolutionary intellectual. McLaren (2018) critiques what he calls the "free enterprise intellectual" as follows:

With internet-fueled self-absorption, their brainpans sodden with fast-food-delivery alternative facts and shovel-ready solutions for any uncomfortable or perplexing situation, free enterprise intellectuals customize their reality like they do their wardrobe, and play the claqueur for whatever political position they feel might give them a leg up on their competitors at any given moment or in any given situation. With such free enterprise intellectuals gaining ascendency in the social media and mainstream corporate cable networks, and where working in teacher education programs does not guarantee immunity from their attitudes and ideas, we might ask in desperation: Is there no implanted hope in today's approach to teaching? With such a negative anthropology and without an inherent vision of what society could become, it is very difficult for any progressive pedagogy to succeed, let alone a revolutionary critical pedagogy. If our worldview is mortgaged to mimetic desire-the desire for what another desires (Girard, 1979) - and founded upon a scarcity of difference rather than abundance of diversity, our calculating minds will have a very hard time knowing how to live inside of the dialectical criticality of revolutionary critical pedagogy where orthopraxis (right action) serves as a consummate threat to self-ignorance. (p. 133)

Further questions stem from the nature and purpose of our public intellectuals and to what extent they have access to diverse ways of seeing the world, whether the academy can support or hinder intellectuals from engaging in the public arena, or whether it censors particular positions from public consumption through its ties to corporate interests and its privileging of Western knowledges linked to prevailing commodity aesthetics. These and other questions are what have attracted our concern as we begin to paint our portrait of the intellectual, drawing on Gramsci's concept of the organic intellectual, Giroux's transformative intellectual, and Fischman and McLaren's commentary on the committed intellectual. We posit here the necessity for an intellectual committed to the transformation of existing society into a socialist alternative-one that in the main reflects the humanist writings of Karl Marx. We will refer to this figure as a "revolutionary intellectual" and will attempt to describe her distinguishing features and make a case for her urgent role in today's society.

\section{Why the Public Intellectual?}

As argued above, one of the cardinal motives of the ruling class is to ensure that its social institutions prepare a citizenry that will abide by its rules. Capitalism accomplishes this in complex ways through institutional entanglements that reflect and espouse private property, encourage competition, and giddily valorize the free market as the guardian of 
"commonsense" social relations-as the only logical way of engaging a world seeped in the swamp of commerce and awash in trade. Often disguised behind a veil of public service and magnanimity, education serves the transnational capitalist state in a myriad of ways: as an institution that insinuates itself in processes of social differentiation, participates in systems of classification, and operates according to laws of exclusion that can distinguish, track, reward, and punish students on the basis of race, class, gender, immigrant status, religious affiliation, sexual identification, and acquired cultural capital. The inequalities that define these social relations are viewed, by virtue of the sedimented doxa of the dominant culture, as inevitable, and sometimes even necessary, reflecting a social engineering agenda backed by a facile social Darwinist explanation that since human beings did not develop uniformly, those with greater capacities for success and perseverance will naturally supersede the limitations of less fortunate others. This ideological disposition-that some people were born with an inalienable right to accumulate the greatest possible wealth and power at the expense of others and the health of the planet, and to live by their own rules and interests-is glaringly exemplified in the pivotal arrogance with which Trump and his administration (composed predominately by a cadre of white men) dispatch executive orders, carry out policies that neglect constitutional law with an impertinent indifference, and cavalierly violate international law.

Existing under prevailing regimes of capital, schools have been shown to be silent accomplices of the state, institutions whose hidden curricula ensure the reproduction of a servile workforce designed to remain perpetually indisposed to challenging current relations of production (McLaren, 2000). While it is true that radical educators and students have always resisted the laws of tendency toward institutional indoctrination, this does little to discredit the prevailing reality that the reproductive process of schooling remains largely unchallenged in its role of manufacturing the historic-specific consensual values and responsibilities required by citizens to drive capitalism forward-a dehumanizing "work ethic," a moral code consisting of absolute reverence for hierarchy, a respect for academic pedigree, and an acceptance of the capitalist marketplace as both the means of success and final arbiter of the meaning of success. Thus, despite concerted effects by students and teachers to engage in organized efforts to transform the social role of schools, institutions of education are unlikely in the near future to be sufficiently capable of preparing a critical citizenry with the necessary capacity to challenge and transform the capitalist status quo or consider even the mildest of socialist alternatives to the reigning capitalist social relations (McLaren, 2006). Yet at the same time we argue that schools are necessary sites for such a transformation, even if currently insufficient.

Critical intellectuals presumably develop the necessary critical acumen to question these commonsense notions of organizing life around capitalist exchange relations and to see them not only as socially produced but also as serving the interests of the ruling class. There is very little that is "natural" or "commonsensical" about relations of exploitation and alienation or the logic of abstraction.

Both the free-market intellectual and the revolutionary intellectual have traditionally been characterized as highly educated, well read, and filled with an insatiable curiosity 
and thirst for knowledge (Jacoby, 2000). The image of conservative intellectual William F. Buckley comes immediately to mind, his clipboard perched comfortably on his lap, sharing space with his King Charles Spaniel, his head tilted in supercilious rapture as he deploys a sesquipedalian vocabulary against his adversaries in a carefully concocted trans-Atlantic accent that bristles with condescension. Buckley was most visibly rattled during his battles with Gore Vidal, an antagonist whom he loathed but who could best him on any topic. During a storied interview with Noam Chomsky on Buckley's syndicated television program, Firing Line, Chomsky's razor-sharp arguments had Buckley gearing up his mandibles, twitching his gunmetal temples, and clenching his eyes, confirming to many that Buckley was entirely out of Chomsky's league, despite Buckley's High Church, mid-Atlantic accent (taught to actors in the Hollywood studios of the 1930 s and 1940s) that was curdled by an ascendant tincture of Southern drawl that softened somewhat the supercilious inflection that very likely was spawned during his education at Yale, where he was a member of the infamous Skull and Bones society. Dissenting intellectuals such as Vidal and Chomsky were well versed theoretically and fearless in contesting prevailing truths, especially of the tepid liberal consensus variety. We characterize them as dissenters because their criticality often exposed the various interests of the custodians of the American empire. Just as there exist dissenting intellectuals, there also exist organic intellectuals who have been bred in the Ivy League universities to support-and defend if necessary-existing social and cultural norms and whose understandings of the world in the main reflect conservative Western views. Organic intellectuals can be found within both progressive and conservative camps. It is not uncommon for the opinions of both groups to be coopted by politicians who use them strategically in order to serve their own personal economic and political interests and to remain popular with their constituents.

Public intellectuals have traditionally sought to engage citizens on issues of political concern that affect the common good, usually by publishing their ideas in magazines, newspapers, and books, and via other popular outlets such as public speaking engagements and as guests on television shows. In current times, public intellectuals can be found writing for online news agencies and blogs and accepting interviews or other speaking engagements that have popular appeal to a mass audience. Their goals are to engage the public and influence public opinion.

Dissident public intellectuals challenge public opinion on a host of issues, engaging in questions of class, power, privilege, politics, and ideology that are often out of the range of the popular broadcast media. And for that reason they do not get the same degree of public exposure as right-wing, free-market intellectuals who calibrate their ideas for pro-military, God-fearing, and patriotic audiences.

Public intellectuals thus serve a crucial role in the social formation of any society, because they engage people in questioning social, economic, and political issues in diverse ways. Of course public intellectuals are often censored in more closed social systems such as China and Russia and can function in their capacity to critically inform the public only to the extent that they have freedom to engage honestly in venues where they are invited to share their views. Public intellectuals play a vital role in any 
democracy-challenging politicians and governments in diverse ways to live up their promises. Note that we are not suggesting that democracy exists within capitalist social relations outside of its formal trappings; it exists only to the extent that it encourages the proliferation of diverse opinions and invites criticism from its citizens, thereby enhancing the possibilities of creating a critically informed citizenry, which, all else being equal, would support more direct and reciprocal forms of participation, such as communal and neighborhood councils.

Of signal importance, then, is the extent to which the public intellectual is critically attuned to the specific issues of the day and to the experiences of those most affected by particular policies and political actions and discourses. This is an axiomatic concern that we do not take lightly. Too often those who are speaking in the public arena about issues impacting the most disenfranchised communities are so far removed from the day-to-day realities experienced by these diverse constituencies that they cannot truly examine the problem through the lenses of the people most affected. Too often our public intellectuals are versed within the Western canon alone, whose perimeters force a preponderance of attention to issues that arise out of a politics of consumption, and have few theoretical tools for understanding of the objective material conditions that affect subaltern groups. Further, they lack an understanding of the cosmovisions of nonWestern peoples and societies. In discussions of global reach, this often results in the production of information rather than knowledge, since in this case cultural critique consists not in a systematic interrogation of the materiality of everyday life but rather constitutes the flabby and prurient reflections of the avant-garde flâneur who chooses to glide across the crusted layers of social life on the strength of his observational skills alone, seeking excitement in the exotica of unknown and unmeasurable lives, and who often wallows in self-serving observations freighted with ruling-class arrogance and captured in the Ivy League echo chamber of the sociological voyeur. While we do not endorse the gravity-defying sentiment among some postmodern theorists that there exists no objective reality, we do conclude that systems of intelligibility are situated and can differ based upon the geopolitical and epistemological standpoints within which we, as corporeal bodies carrying specific cultural histories, are positioned, and that some people are positioned to glean deeper insights than others with respect to their own experiences and positionality. There is little room in our political project for a judgmental relativism that would render capitalist exploitation and the suffering of masses of the population as simply a language game, an effect of discourse, and wholly subjective. In our contemporary space, postmodern intellectuals have replaced reason with opinion, explanation with observation, knowledge with opportunity, facts with the way one thinks about them, and understanding of an idea with its tacit approval-all of which takes place in a world where historical depth of field is already compressed by dominant media apparatuses into a series of soundbites and memes. We live in a world where "insidious postmodern promises of emancipation via avid consumption of and participation in the Internet's pleasure-filled celebrity bazaar" proliferate (San Juan, 2013, p. 80). We agree with Paula Allman (1999) in asserting that there are different levels of truth: meta-transhistorical truths, which appear to hold across the history of humanity 
but about which we must always remain skeptical; transhistorical truths, yet which are susceptible to future revision; truths that are specific to a particular social formation; and conjuncturally specific truths, which are transient but attain validity in the contextual specificity of the developmental processes of which they are a part and which may endure beyond that specific conjecture. While we agree that epistemological viewpoints about the world are value-laden and theory-laden, unlike postmodernists, we do not believe that we can alter the world simply by changing our beliefs about it. Nor do we wish to bleed epistemological objectivity into ontological objectivity, and claim that because there is no epistemologically objective view of the world there cannot exist an objective world ontologically. When we embrace different worldviews or cosmovisions, this is not tantamount to inhabiting objectively different worlds. The specific social formation that has attracted the interest of whom we shall call "the revolutionary intellectual" is capitalism, and the essential gesture of the revolutionary intellectual is to contribute to the formation of a counterpublic sphere by making the case for a socialist alternative to capitalism.

This of course suggests that revolutionary intellectuals must be connected to the people most affected by the issues that they write and speak about. Particularly, they must have close ties to those communities whose ways of knowing may differ significantly from the ways in which they traditionally have generally been trained, including indigenous communities, communities of color, LGBTQIA cadres, and other marginalized groups. The public intellectual cannot ethically respond to every situation as an "expert" but must be able to recognize his or her limitations, while at the same time seeking guidance from community members. More will be said about the revolutionary intellectual at the conclusion of this chapter.

\section{The Public Intellectual Historically Defined}

In his provocative book The Last Intellectuals (1987), Russell Jacoby offers readers an historical account of the public intellectual in the early 20 th century and argues that although intellectuals remain firmly ensconced in the body politic, their role has shifted from engagement with the broader public to one in which the public has been truncated into audiences working mainly within university research silos. Jacoby bemoans the loss of the public intellectual who was once independent of academia and thus was able to define for himself the social issues he wished to tackle and how he wished to tackle them. In Jacoby's analysis, the public intellectual emerged from the au courant salons of bohemian culture looking somewhat gaunt and forlorn-clearly markers of deep, sustained, and possibly harrowingly reflective thought-during the point at which his (the leading intellectuals of the day were invariably men) intellect, marinated in deep discussion among the leading exponents of the haute bourgeoisie, was deemed ready to be consumed by a public thirsting for erudition. A successful public intellectual needed to be 
thoroughly engaged in and preoccupied with the most pressing conflicts of the day, working alongside other kindred spirits and enlivening the public with splendid displays of learnedness and wit. In Greenwich Village, for example, intellectuals, philosophers, artists, musicians, and others-cultivated dissidents who wished to separate from the establishment-gathered at local cafés discussing with verve and excitement the granular insights of Hegel, Marx, Marcuse, and the Beats, and debating the Vietnam war. They were content to find the cheapest apartments and lofts (such places did exist in the 1950s!) and fuel their burgeoning imaginations at cheap eateries in order to dedicate the greatest time and energy to their critical and creative pursuits until, inevitably, the entelechy of personhood became usurped by the concept of human capital under the relentless assault of late technocratic modernity. At that moment the pursuit of a critical citizenship gave way to the pursuits of the consumer citizen, as intellectuals began to serve particular brands, usually their universities, but also became identified with certain television corporations such as MSNBC or Fox News, or talk radio stations. Notwithstanding their creative acts of lese-majesté that savaged the literary, artistic, and political potentates of the day, public intellectuals were deemed a necessary counterpoint to the commonsense dictums of the day. Today they are more carefully vetted by their corporate paymasters and tend to survive as "edutainers" rather than truth-sayers.

For those of us who enjoy intersubjective pursuits that are often associated with dissident intellectuals--poring over books, thinking and writing and discussing as part of a larger transformative political.project-this romantic notion of the bohemian lifestyle seems an ideal gesture, an escape from the commodity-driven life that defines most of our lives. However, the economic boom that marked the end of World War II, the "red scare," and the development of freeways that drove city-dwellers into the suburbs facilitated the dispersal of intellectuals into the suburban hinterlands and foreshadowed what Jacoby considers the demise of public intellectuals as a force for shaping public opinion and the public good (Jacoby, 2000). Stuck in the more affluent yet cookie-cutter homes in the suburbs and in need of transportation into the city to escape their mind-numbing surroundings, consisting of neighbors obsessed by lawnmowers and lawn chairs, paved driveways, sterile patios affixed with matching aluminum glider rockers, backyard tiki bars with flaming torches, and Korla Pandit on the Hammond organ playing Miserlou, intellectuals found it impossible to survive without sustained and often grudging work. The academy became a place of reprieve, a space within which they would presumably have some semblance of their previous intellectual freedoms but also be able to sustain the new lifestyles to which they were becoming accustomed.

For many of us this historical and romanticized image of the intellectual still seems very attractive and invites us to ponder a life of intellectual pursuits beyond the competitive bustle and bluster of commodity culture. However, there is no doubt that the privileged position of the bohemian was not available to the poorest sectors of the population, women, and people of color. Indeed, while these White intellectuals were deconstructing the economic conditions that sustained racialized and sexist social tensions, men and women of color were living the realities of oppression that bohemia was merely contemplating. Although bohemians lived with scarcity, their relative privilege as White, schooled city folk protected them from the realities of oppression that the rest 
of the working class was experiencing. Certainly it is one thing to read, think, and write about injustice and another to live it. While White intellectuals mourned the loss of bohemia and the move to a university life (which now appears to be valuing research grants over public intellectual engagement), intellectuals of color and women welcomed their increased presence in the university that came about in the wake of the civil rights movement (Darder, 2012). These unacknowledged intellectuals would finally have the opportunity not only to engage in social justice work but also to be able to support themselves and their families. The bohemia of the early 20 th century was not available to people of color who at the time still lived under the life-denying assault of Jim Crow laws. For people of color, an intellectual life would never have been possible without the financial security that the university provided. This was especially true if they wished to critique the status quo-something difficult to engage without the academic freedom provided by tenure. For those whose histories of oppression are defined by economic insecurity, to risk financial security is not an option. Indeed, Jacoby's characterizations of the public intellectual as bohemia precludes the many public intellectuals who did not have access to bohemia but who made important contributions to public opinion-and in doing so made history. Jacoby's narrow description of the public intellectual, then, excludes by definition the contributions of public intellectuals of color, including Martin Luther King, Jr., Malcolm X, Angela Davis, Che Guevara, and others. Indeed, Jacoby argues that while 1960 s activists made a significant contribution to social change, their presence within the public sphere did not remain for long.

To mourn bohemia, then, is in one sense, at least, tantamount to lamenting a countercultual community that was almost exclusively White. While articulating important critiques of racialized and gendered exclusion in U.S. society, and the U.S. war in Vietnam, the intellectuals of bohemia nevertheless remained beneficiaries of its privilege and status, marking them, in Jacoby's terms, as the last of the public intellectuals. While their commentaries were often timely and important critiques of the issues of the day, the same recognition was not given to Black and Brown public intellectuals, such as Paul Robeson, James Baldwin, Jóse Martí, or Pedro Albizu Campos, to name just a few. While this is less true today, it's a far cry from meeting any reasonable standard of equity.

Rather than mourn a system that was possible predominantly for White men only, it is important to allow our definitions of public intellectuals to develop alongside the new face of public intellectuals-the women and men of color who are redefining what it means to be a public intellectual in ways that support their interests and their strengths as community members with diverse ways of knowing and thinking. In the wake of the bohemian intellectual, a new public intellectual has arisen-one whose life experiences 'may lend themselves to a keener understanding of our world's greatest problems and to very different ways of engaging in the public sphere.

The university, within which intellectual life became a career pursuit and whose research for the most part remained incubated in corporately controlled environments, cannot evade responsibility from the political apathy that afflicted U.S. society following the social and political struggles of the 1960 (Jacoby, 2000). Public intellectuals, now 
housed almost exclusively in academia, have been less able to attend to the challenge of influencing and transforming public life. Indeed, the academy has increasingly become an exclusive club in which scholars speak and write mainly to each other. Journals and conferences are often highly exclusive and require a disciplinary language and theoretical register that often does not translate readily into the public lexicon. Those who opt to engage in more public arenas must do so in addition to an already extremely demanding work schedule within the university, including publishing in top-tier publications that are generally read by a handful of one's own colleagues, already versed in the same area. Add to this the time-consuming practice of service activities to the profession and to the university and you have academics who increasingly feel strapped onto a hydra-headed structure of unending commitments and service to the university "brand." Our work, once heralded as the production of knowledge for the betterment of society, now suffers from regurgitation and the arid circulation of the same problems and solutions. Fresh ideas require time and energy and an avid audience that can engage our work with urgency and excitement and push us to think more clearly.

Academics of color who often engage in nontraditional research methods and study topics often presumed by Western university standards as trivial or less scientific must especially tread a fine line to remain viable candidates for tenure (Monzó, 2014). The supreme contradiction lies, therefore, in the fact that the new academics who are significantly interested in shaping public opinion and possess the community-based ties to shed a fresh light on social, economic, and political issues are less able to engage this public arena. Nonetheless, rather than accepting the fall of the public intellectual as an evitable failure of modernity, as traditionalists would have it, some of today's public intellectuals have refused the happy oblivion of an unexamined life occulted by the imperatives of capital and absent of meaningful social critique and have redefined their purpose, how to engage publicly, and even who their public is and ought to be. In this way, what was traditionally an elitist role, characterized by a proclivity for the avoidance of manual labor and an opportunity for a privileged life of reading, writing, and thinking about the world (albeit through the old White canons that narrowly comprised intellectualism), has broadened to include men and women of color and other nondominant groups who, for centuries, had been publicly engaged intellectuals but did not have the "right" physical characteristics to be recognized as such or who refused to serve as the majordomos of White department heads, performing a fatuous service for the behoof of the reputability of White institutions or to enhance the well-being of their brand. Yet the struggle for professors of color is far from over. Stephanie Evans (2007) reports on efforts to challenge the egregious conditions facing African American women in university positions:

The challenges of having to be twice as good to get half the recognition that are present for White women are magnified for scholars of color who don't have the credibility that Whiteness provides. While it is futile to say who has it "worse" by ranking oppressions of gender or race, it is crucial to recognize that each demographic 
carries with it a unique standpoint and a unique set of challenges. Black women, while suffering a distinct set of educational and intellectual stereotypes, are still subject to what I call extraordinary scrutiny. This scrutiny takes place without critical analysis of the centuries of debilitating oppression that we have had to overcome. "Gender [and racial] stereotyping occurs in recognizable patterns" and must be identified and eliminated. But simply stopping the leakage is not enough. The flow of women and minority faculty must be increased; every point in the pipeline must be strengthened. Where programs are in place to enhance minority faculty numbers, these programs must be supported and built upon. Some programs such as those in the federal TRIO structure (e.g., Talent Search, Upward Bound, McNair Scholars) provide vital entry points into higher education for underrepresented populations and are essential networks that are helping to counterbalance the legacy of exclusion. In addition, programs like Preparing Future Faculty (originated at Howard University) and the Southern Regional Educational Board's (SREB) Doctoral Scholars Program are examples of possible interventions. This type of sustained support is what SREB's Ansley Abraham calls "more than a check and a handshake." As a second way to improve the pipeline, for hiring purposes, campus administrators can consult professional organizations that focus on race. For example, in African American studies, scholarly groups such as the Association for the Study of African American Life and History and the National Council for Black Studies provide much-needed human and material resources for scholarly leadership. Race or gender caucuses in traditional disciplinary professional organizations offer a third possible resource available to help come the "we can't find any good candidates" scenario. The Woodrow Wilson National Fellowship Foundation's recent study "Diversity and the Ph.D.: A Review of Efforts to Broaden Race and Ethnicity in U.S. Doctoral Education" shows that the record for diversity is poor and getting worse. From elementary schools to higher education, inequities must be eliminated or the unnecessary drain of human potential will continue.

Jacoby (2000) concludes that any group of intellectuals learning and working together can make an important difference, not only in their attempts to respond to public needs but in their own development as intellectuals.

\section{A Pedagogy of the Subaltern}

What we are calling the revolutionary intellectual functions as an organic connection to subaltern constituencies, an interpretive bridge linking dialectically understandings of the deep systemic and structural arrangements of society and the lived experiences of the popular classes. Here the goal is to challenge the values and ideologies that are perceived as natural and common sense simply because this is the only way that they have been named and interpreted. Antonio Gramsci (1971), the renowned Italian communist of the early oth century, referred to these individuals as organic intellectuals. Gramsci emphasized the dialectical unity of political and civil society, and the dialectical relation of force and 
consent, as well as distinguished political society and civil society as moments within the wider hegemonic formation of the modern state (Thomas, 2011). Gramsci (1971) elaborated his theory of hegemony as a dialectical process in which ruling-class interests were maintained through the formation of what he called the integral state. In his own words:

[I]n the West, there was a proper relation between State and civil society and when the State trembled a sturdy structure of civil society was at once revealed. The State was only an outer ditch, behind which there stood a powerful system of fortresses and earthworks. (p. 238)

Hegemony, according to Gramsci, is maintained by both consent and coercion, but in the industrialized West, it is most evident as the manufacture of consent (to use Chomsky's term) procured through false narratives and ideologies about meritocracy and democracy that helps keep capitalism intact. Indeed, the military-industrial complex, which includes policing and prisons in the United States and other Western countries, is so advanced that to topple such a monstrosity would take a revolution of unrivaled proportions. According to Gramsci, in the West, a war of maneuver must be preceded by a war of position - an ideological war in which the people begin to question what they have come to understand as common sense and to recognize the false premises that delineate the ruling ideas of the state (in our case, those manufacturing in liberal democracies such as the U.S.), noting instead how the common sense that they have been taught all of their lives is aligned with the interests of the capitalist class.

But this is no easy task, for the common sense that has been developed through years of ideological production in order to discourage citizens from questioning the status quo is as secure as if protected by an electrified fence-or, in the language of the internet, a digital fence. According to Gramsci (1971), common sense is not something rigid and impermeable but rather "a conception which, even in the brain of one individual, is fragmented, incoherent, and inconsequential" (pp. 419-420), yet it is accepted because it is "not something rigid and immobile, but is continually transforming itself, enriching itself with scientific ideas and philosophical opinions, which have entered ordinary life" (p. 326). Gramsci discussed "good sense" as counterintuitive, counter-hegemonic ideas and opinions articulated by the subaltern or those whose positioning in society was subordinate to the ruling capitalist class. Gramsci recognized that good sense could play an important role in making visible the reality that common sense was not natural but rather a form of consent on the part of the wider public that was manufactured ideologically in the interests of the ruling class and rendered legitimate through repetitive messages and acts of state-sponsored institutions. Gramsci's organic intellectual required an observer who could recognize and cultivate the suppressed impulses of liberation dormant within subaltern groups, a cultural worker whose ideas and actions brushed against the grain of common sense fostered by those who made up the dominant hegemonic bloc. Gramsci posited the organic intellectual as having a structural view of reality, gleaned from special training, critical thinking, and/or a particular sensitivity in grasping the subtle contrivances exercised by the capitalist class in rendering the subaltern 
class unwitting participants in their own subjugation. Gramsci believed that organic intellectuals could bring some formal unity and cohesiveness to the particular worldviews of subaltern groups and, in rendering this relation a reciprocal one, both the subaltern and the organic intellectual could lend a clarity of insight into the exploitation and alienation created by the capitalist mode of production (Mayo, 2010, 2015). In Paulo Friere's (1970) view, it is the oppressed who need to lead the revolution to liberate humanity:

This, then, is the great humanistic and historical task of the oppressed: to liberate themselves and their oppressors as well. The oppressors who oppress, exploit, and rape by virtue of their power, cannot find in this power the strength to liberate either the oppressed or themselves. Only power that springs from the weakness of the oppressed will be sufficiently strong to free both. (p. 44)

Fischman and McLaren (2005) add a new dimension to the concept of the organic intellectual, claiming that organic intellectuals must be ethically committed intellectuals, claiming a preferential obligation to serve the popular classes, and willing to stand with and among the oppressed rather than for the oppressed. This is a necessity if the subaltern is to lead the way to liberation, for it is a recognition of the reciprocal trust between the subaltern and committed intellectual that gives both parties the courage and strength to affirm their humanity and to demand a new social order that will equally serve all.

In these theoretical articulations, neither the organic or the committed intellectuals were positioned as public intellectuals, yet we argue that indeed they must be. Certainly if the goal of the public intellectual is to influence public opinion with the aim of bringing about the public good, then certainly the public intellectual must bridge her intellectual understanding with the rich and variegated experiential knowledges offered by subaltern groups. Furthermore, the public intellectual cannot stand idly by once her public outcry has actively engaged the public. To do so would be tantamount to mirroring the negative stereotype of the armchair ethnographer who riles up the community to challenge the oppressive practices of those in power, but then, after her revolutionaryfor-a-day fist-pumping subsides, steps back into the normative hegemony of the leftliberal academy, safely ensconced in the contiguous security apparatuses of her tenured research position, allowing the community to suffer in isolation the consequences of the actions that she incited in her missionary zeal as a transformer.

\section{Praxis and the Intellectual}

Henry Giroux $(1988,2011)$ discusses the important role that teachers play as transformational intellectuals. Here he reflects that teachers are intellectuals who ought to be using their critical-thinking skills to develop curriculum and pedagogical practices that are not only culturally appropriate for their students but that address their particular interests 
in the context of contributing to the public good. In addition, Giroux argues that the transformative intellectual must engage students in the political process, which consists of being critical of social issues and engaging with the most heated political issues of the day. Further, Giroux argues that pedagogical practices must be political-that the pedagogical tools used by teachers must be empowering and transform them into Subjects. But he also recognizes that politics has a pedagogical dimension, since every political act has a teachable moment, for good or for ill. Hence he argues that "[c]entral to the category of transformative intellectual is the necessity of making the pedagogical more political and the political more pedagogical" (1988, p. 127). Here we arrive at another important point in the conception of a public intellectual, which is that it is insufficient to think of an intellectual as merely someone who imparts his or her expertise. Rather, the expertise of a public intellectual must come out of engaged scholarship-it must be grounded organically in the real lived experiences of the oppressed. The public intellectual must also engage in praxis, the development of theory grounded in action and reflection.

Many of today's public intellectuals fail to engage the people in both micropolitical and macropolitical ways, sidestepping the reality of current university corporate interests in order to remain employed. Of course, as ethical human beings we cannot ignore the dire immediate needs of the oppressed. After all, it is in the achievement of small successes against the highly integrated power structures of global capitalism associated with the economic exploitation of the masses, ecological genocide, and bureaucratic domination that we find real hope-hope that is based on evidence that reveals that we can, in effect, make change happen - that it is through our agency and struggle alongside our research partners, including those who are the objects of our research, that history is made. Social-change projects at the micropolitical or local level can become the initial building blocks by which we slowly create a movement against broader and more abstract structures of exploitation and oppression. But these local efforts must be analyzed coextensively, in tandem with larger structures of mediation-the social relations of economic production, the physical environment, and cultural, social, and institutional constraints. Again, this requires a firm grasp of theory, of being able to read both the word and the world - that is, of being able to develop a dialectical literacy that allows for a contrapuntal reading of specific social arrangements against those structures of mediation that make up the complex and concrete social totality. It requires an understanding of how material use values are only available in the commodity form, and how use value is internally related and thus inseparable from the exchange value of the commodity, which is determined by labor time. It requires recognizing that the wealth that is constituted by capitalist societies is not the vast array of use values-but value itself.

Marx (1867/2011) argued that within the existing capitalist division of labor (the separation between the ruling classes who own the means of production and the working classes who do not), the separation of manual labor from intellectual labor was an important reflection of and inducement to inequality. Marxists maintain that activities that fail to engage significantly both body and mind are antiseptically abstracting away fragments of the self and are therefore engaged in the process of a life-denying species of social reproduction that public intellectuals ought to be in the service of eradicating. 
This view is consistent with Marx's revolutionary theory of consciousness that grasps the internal relations between thought and human practice, or consciousness and material reality. Such a theory of consciousness underscores the futility in revising existing asymmetrical relations of power and privilege and their functional effectivity without challenging the way power is constituted within the social divisions that mark capitalist social relations. Viewed from this perspective, there is little daylight between the capitalist colonization of subjectivity and the transcendent aspiration of the American dream.

Of course, those intellectuals who focus on micropolitical-level "reforms" fail to recognize that even problems that appear to be bounded and temporally and spatially nearer to us are still configured through capitalist production processes. The heterotemporal and spatial features of everyday life can be accommodated within the capitalist production process, and understanding how this is possible requires dialectical understanding. For example, examining family dynamics within low-income working-class racialized communities requires an understanding of how the dynamics that play outparental and child conflicts, schools that fail children, lack of parental resources, and other family social ills associated with immigrant communities-are part and parcel of a social structure that requires a "failing" segment of the population that can be pathologized, rendered best suited for exploitative low-skill and low-wage work, and scapegoated during economic crises (Monzó, 2015). The critical public intellectual is able to undertake structural analysis with those with whom he engages, bringing forth a mutually informed criticality that is currently lacking in the public sphere.

\section{WAR AND THE RESTRUCTURING OF THE ECONOMY}

The revolutionary intellectual includes all the aforementioned aspects of public engagement but does so with the aim of developing a socialist imaginary among the public such that we can develop a classless alternative to capitalism that is free of racism, sexism, and all the other debilitating sequelae of antagonisms whose interfluence has brought about our commodity-riven culture.

We need a revolutionary intellectual precisely because her incumbent task is to peel away the membrane of innocence through which ideology is both mediated and legitimized. While our knees tremble at the sight of the melting, mist-wreathed eyes of a son who has lost his coalminer father after a long and painful struggle with silicosis, we are reluctant to raise questions about the economic and environmental conditions that cause silicosis to go unchecked. We are told that the coal mines will flourish when the environmental regulations are relaxed, and the miners will once again have the opportunity to house, feed, and clothe their families. The revolutionary intellectual understands such a ploy as putting lipstick on the pig, as the country moves to cheaper, cleanerburning natural gas that is produced through fracking. None of this bodes well for human 
health. As a public relations move, it's bound to backfire, like the Marlboro Man, Wayne McLaren (no relation to this co-author), dying of lung cancer. As for fracking, which releases known carcinogens and toxins into the ground, it's like burning your furniture to heat your house. In today's post-truth political era, the revolutionary intellectual is needed more than ever.

Recently our eyes were set ablaze in a fit of glory at the evening launch of 59 missiles from a U.S. warship arching toward their target in Syria. Our passion is orchestrated by gloating newscasters caught up in the mimetic contagion of the violence. MSNBC's Brian Williams misappropriated a quotation from a song by the late Leonard Cohen as the missiles he so adores sped through the night sky in glorious arcs of destruction: "I am guided by the beauty of our weapons" (Moran, 2017). And yet, during a Fox News interview with Maria Bartiromo, President Trump couldn't recall the country he just bombed, but could recall the sumptuous details of the delicious chocolate cake he was eating with China's President Xi (very likely Mar-a-Lago's signature Trump Chocolate Cake festooned with "four dots" of vanilla sauce, and served with dark chocolate sorbet and a sliver of white chocolate stamped TRUMP) when he ordered the missiles to head toward "Iraq." Later, he was corrected by his interviewer (Collins, 2017), but not before describing the missile launch as "incredible, brilliant and genius," which Osita Nwanevu (2017) in an article in The Slatest referred to as "war described in precisely the manner a schoolchild would relay the details of a field trip to a science museum."

Sooner than later, even a potentate like Trump may need some help to make even his own conservative base understand his rationale for Visa-swiping the Constitution by giving unlimited funding to the Pentagon and for the following remarks he made at a recent press conference:

We have given them [the military] total authorization, and that's what they're doing, and frankly, that's why they've been so successful lately. Take a look at what's happened over the last eight weeks and compare it with the last eight years. There is a tremendous difference. Tremendous difference.

Total authorization granted to the military? Trump sounds very much like the senators under the emperor Tiberius who told him that they would accept any legislation he sent to them, sight unseen. In doing so, they were strongly rebuked by the emperor: What, for instance, if the emperor had gone mad? Or had become an enemy of Rome? Trump just described the United States as an unconstitutional government, through what William Boardman (2017) calls "the abdication of civilian control of the US military." What exceptions-if any-exist to "total authorization" remain a mystery, even to his train of obsequious, spittoon-carrying and cloak-holding officials that make up his inner circle. What isn't a mystery is the increasing militarization of the U.S. economy. We have learned this from revolutionary intellectuals such as Noam Chomsky, to name perhaps the most influential revolutionary intellectual in the United States. Yet, revolutionary intellectuals such as Chomsky rarely appear in mainstream media outlets. They are routinely relegated to alternative media sites. But still, their analysis can be found and scrutinized by discerning teachers who can direct their students to alternative 
websites-the alternative websites, that is, that don't truck in "alternative facts." What is needed more than ever are revolutionary intellectuals who can deepen capital's crisis of legitimacy and make it difficult to for the Trump administration to follow the path of destruction to which it is headed.

For instance, William Robinson points to the deep structural dynamics in the global capitalist system that are pushing ruling groups toward war. Robinson describes this crisis as "an intractable structural crisis of overaccumulation and of legitimacy." Cyclical crises, or recessions, occur about every 10 years in the capitalist system and typically last some 18 months. There were recessions in the early 1980 s, the early 1990 s, and the early 2000 s. The only way out of crisis is to restructure the system and, according to Robinson (2017), this occurs approximately every 40 to 50 years:

A new wave of colonialism and imperialism resolved the first recorded structural crisis of the 1870 s and 1880 os. The next structural, the Great Depression of the 1930 s, was resolved through a new type of redistributive capitalism, referred to as the "class compromise" of Fordism-Keynesianism, social democracy, New Deal capitalism, and so on. Capital responded to the structural crisis of the 1970 os by going global. The emerging transnational capitalist class, or TCC, promoted vast neoliberal restructuring, trade liberalization, and integration of the world economy. The global economy experienced a boom in the late 2oth century as the former socialist countries entered the global market and as capital, liberated from nation-state constraints, unleashed a vast new round of accumulation worldwide. The TCC unloaded surpluses and resumed profit-making in the emerging globally integrated production and financial system through the acquisition of privatized assets, the extension of mining and agro-industrial investment on the heels of the displacement of hundreds of millions from the countryside, a new wave of industrial expansion assisted by the revolution in Computer and Information Technology (CIT)... The global financial collapse of 2008 marked the onset of a new structural crisis of overaccumulation, which refers to accumulated capital that cannot find outlets for profitable reinvestment. Data from 2010 showed, for instance, that companies from the United States were sitting on $\$ 1.8$ trillion in uninvested cash that year.

Robinson (2017) holds, justly, that in recent years neoliberal states have turned to four mechanisms to assist the TCC in unloading surplus and sustaining accumulation in the face of economic stagnation: raiding and sacking of public budgets, expanding both consumer and government credit to sustain spending, consumption, and militarized accumulation. These mechanisms create instability by increasing the gap between the productive economy and "fictitious capital." And there is increasing need for repressive forms of social control in order to sustain accumulation, which, Robinson notes, accounts for the TCC's interest in war; in military spending (the Trump administration's increase of US $\$ 55$ billion in the Pentagon budget); in sustaining social conflict in the Middle East and other areas; and in accumulation through state-organized systems of repression, including surveillance, prisons and immigrant detention centers, and private mercenaries. 
The capitalist economy will keep on rolling like Old Man River under the tutelage of the free-market intellectual, but the hallmark of this reality is that more and more human beings will become disposable, their job futures mortgaged to dramatic innovations in high technology. The capitalist economy in this instance possesses about as much capacity to become compassionate and sympathetic as a junkyard dog. According to a recent World Bank Study, 57 percent of jobs in Organisation for Economic Co-operation and Development (OECD) countries are vulnerable to replacement within the next 20 years (Howard, 2017). Many experts think this is a more serious problem than the export of jobs abroad. Robots equipped with the latest developments in artificial intelligence will work $24 / 7$ without complaint, and, as Howard (2017) notes, "they don't need health insurance and they don't join unions."

The digitization of money permits it to move quickly through the global economy's financial circuits of accumulation and plays an integrative role for the transnational capitalist class, making transnational finance capital "the hegemonic fraction of capital on a world scale" (Robinson, 2016). The very life-world itself, including the social relations that shape our educational institutions, has become progressively penetrated by the coloniality of power bolstered by the acceleration of deregulated capital, and thus education today is playing a greatly expanded role in the transnationalization of education as a service commodity for the benefit of transnationally oriented elites, minus previous constraints that were once imposed by the nation-state and the working class. There has always been a contradiction between the needs of accumulation and the needs of social reproduction. Today, with the rise of superfluous labor, growing immiseration and precaritized workers, and the "bifurcation in the world's workforce between high-skilled tech and knowledge workers and those relegated to McJobs at best, or simply surplus labor" (Robinson, 2016, p. 10), education is exercising an increasingly repressive role. The economy once needed a workforce that was "highly trained, intelligent, and self-directed," which resulted in people's ability to think and to engage in social justice struggles; today, however,

alongside a small and shrinking group of high-skilled and high-paid workers, global capitalism needs a workforce with less autonomy and creative abilities, and one subject to ever more intense mechanisms of social control in the face of a rising tide of superfluous labor and ever more widespread immiseration and insecurity.

(Robinson, 2016, p. 10)

Robinson also notes that the political and business elites of the transnational capitalist class are being educated and groomed by a select number of global elite universities such as Harvard, Cambridge, Oxford, Tokyo University, and the Indian Institute of Technology, and at a level below these universities exist institutions of higher education that are training individuals for what Robinson (2016, p. 11) calls "a mercantile insertion in to the upper rungs of the global labor market." This has occurred in tandem with a call for universal primary education by the OECD, European Union, United Nations, World Bank, International Monetary Fund, and the World Trade Organization in order to prepare 
the labor force for global capitalism, and a call for the privatization of education and a neoliberal policy framework for school reform. Public ownership of and governmental planning for higher education institutions is being rapidly replaced by a neoliberal restructuring of education involving the privatization of secondary and higher education which, in many cases (such as charter schools), demands public-sector financing of private institutions, and a disastrous switch from public funding to tuition-led funding of higher education. As a result, the poorest students, who are shut out from public higher education institutions through student debt bondage, are forced to turn to for-profit private universities; this, Robinson (2016) argues, mirrors the shift in the low-skilled and unskilled labor-intensive phases of global production circuits from the North to the South, bifurcating work into deskilled and high-skilled jobs. And, as Robinson (2016) reports, only 20 percent of global society possesses the resources to finance their education and to join their global elite cohorts as "brain trusts for capital" (p. 13). The inequalities within the global political economy have necessitated extreme measures of repression and social control by the ruling classes.

We need to underscore here that there are organic intellectuals who serve both the transnational capitalist class and subaltern groups and the popular classes. Giroux (2010), for instance, discusses the differences between "hegemonic intellectuals" who serve the interests of the dominant culture and "transformative intellectuals" who, as cultural workers, brush against the grain of existing discourses, cultural practices, and social and institutional relations. We have referred to organic intellectuals who serve the transnational capitalist class as "free-market intellectuals" and those who serve the emancipatory struggles of the popular classes as "dissident" or "revolutionary intellectuals."

\section{FrEe-MARKET INTELLECTUALS ANd Identity Politics}

Faced with the popular and revolutionary uprisings of the 1960 s and the 1970 s as a result of the crisis of hegemony of global capitalism, the organic intellectuals of the emerging TCC (Transnational Capitalist Class) were conscripted by their overlords into service against revolutionary forces from below (i.e., worldwide student rebellions and insurrectionary movements who sought redistributive approaches to economic injustice or the establishment of socialist or communist alternatives to global capitalism). The neoliberal counterrevolution against the welfare state and the demands of the popular classes was as swift as it was vicious, and labor was swiftly resubordinated and effectively subdued worldwide as a result of the transnational mobility of capital and its consolidation by means of interstate systems, which, Robinson (2016) notes, was modeled on deregulation, informalization, deunionization, and flexibilization of labor. These measures paved the way for global capitalism's expansion from core countries into far-reaching global markets through "foreign direct and cross-investment, transnational interlocking of boards of directors, transnational mergers and acquisitions, vast networks of 
outsourcing, subcontracting, joint ventures and alliances, and the establishment of tens of thousands of transnational corporate subsidiaries" (Robinson, 2016, p. 8), which saw the transformation of multinational corporations into "giant global or transnational corporations" (p. 8). Thanks to the leadership of free-market intellectuals, the ruling classes have been highly successful in unleashing carnage throughout the world. Robinson is worth quoting in detail:

The ruling classes have launched farcical wars on drugs, terrorism, immigrants, and gangs (and youth more generally); such wars of social control and dispossession waged against the popular and working classes and the surplus labor population have engulfed social and political institutions, including educational systems. The TCC has taken up the challenge of imposing fear and obedience and assuring the social control of youth, in part, by converting schools into centers for repressive discipline and punitive punishment. The role of schooling in social control is an old theme, but the coupling of the educational system with new systems of mass social control and surveillance appears to be reaching depths hitherto unseen. (p.14).

It is interesting to note how, in the process of the neoliberal counterrevolution, freemarket intellectuals were able to popularize postmodern theory and coopt left-wing neoliberals into "revolution-lite" measures that called for diversity and multiculturalism, and in so doing were careful to avoid any sustained challenge to capitalism. This proved in the end to be an effective way of constructing ideological hegemony. Robinson writes:

This strategy aimed to neuter through cooptation the demands for social justice and anti-capitalist transformation. Dominant groups would now welcome the representation of such diversity in the institutions of capital and power but would suppress, violently if necessary, any struggles to overthrow the capitalist system or simply curb its prerogatives. Some among the historically oppressed groups gained representation in the institutions of power; others aspired to do so. They condemned oppression but banished exploitation from the popular vocabulary. (p. 18)

We see similar processes at work in college campuses throughout the United States. Robinson captures the essence of this political maneuver when he writes, "Dominant groups now praised (even championed) an opposition to racism, intended as personal injury and micro-aggressions, that eclipsed any critique of the macro-aggressions of capitalism and the link between racial oppression and class exploitation" (p. 18). Robinson is correct in asserting that critiques of global capitalism were effectively sidestepped or shrouded from view by resurgent attacks on neoliberalism as a form of governmentality or set of policy initiatives such as privatization and deregulation or flexible accumulation. By focusing on the hermeneutical (subjectivist) and organizational aspects and modalities of neoliberalism and ignoring the structural (objectivist) modes of critique, such as historical materialism, free-market intellectuals masterfully muddled and transmogrified the objective conditions of capitalist exploitation and alienation by appropriating and coopting the discourse of the progressive left and turning it in upon itself, sublimating its own values and rendering them impotent. 
In Latin America, still infected with oligarch-comprador domination, mass pauperization of the indigenous populations, and a manu militari approach, there has been a similar move by the ruling elite. Robinson (2016) reports that the "Indio insurreccionista" (the insurrectionary Indian) who demands control over land and resources has been replaced by the "Indio permitido" (the allowed Indian) who is permitted to seek cultural pluralism and representation within the reigning logic of the capitalist order but not to challenge the property and class relations of the same order.

Nowhere in the mainstream media do we hear about the crisis of capitalism and the need to seek a viable alternative. Rarely do we learn about it within the Eurocentric humanities and the social sciences, except within some select heterodox publications. Robinson's (2017) warning of militarized accumulation appears to be particularly apposite to these times in light of Trump's praise of dictators around the world. The "Beltway boys" will try to educate Trump accordingly in the coming months, counseling him about which dictators are to be legitimized and which are to be shunned. Those who are seeking economic alternatives, such as Venezuelan president Maduro or Bolivian president Evo Morales, are to be demonized or inferiorized while others are to be praised and elevated to the status of allies, their human rights records notwithstanding. Juan Cole (2017) informs us that the United States chooses which political leaders to be allies according to the logic of capital:

Is it as simple as American billionaires feeling threatened by some dictators but not by others, and instructing the US government accordingly? Be a popularly elected politician who talks socialism, and anything less than a perfect human rights record becomes a headline. Be a coup-maker who welcomes the foreign billionaires in to exploit your people, and you can sodomize prisoners of conscience with broomsticks all you like, and Washington won't so much as cough politely in disapproval.

Those whose opinions are customized to fit the ideological platforms and commercial templates of the mainstream media outlets are educated to consider certain leaders respectable and others criminal, following the unholy catechism of the administrative state. Cole (2017) elaborates:

Washington wants Trump to talk dirty about Vladimir Putin of Russia, Kim Jong Un of North Korea, and Nicolás Maduro of Venezuela. (Two of the three were elected and Putin seems genuinely popular). But the Establishment is fine with him praising Abdel Fattah al-Sisi of Egypt (Sisi strong-armed opponents into not running against him, intimidated the press, declared a major party a terrorist organization and killed hundreds of them, and won office with a shameful $97 \%$ of the vote). No one in Washington stands up and gives speeches criticizing Thailand's repressive military junta. And the US Establishment was positively giddy when the corrupt Brazilian oligarchy impeached the elected president of Brazil and replaced her with a corrupt Brazilian oligarch. We haven't heard anything more about either Brasilia or Bangkok on television news. Move along, nothing to see here. Saudi Arabia would be too easy a subject here. 
You've heard less about Salva Kiir Mayardit of South Sudan, who helped plunge his country into a deadly civil war and wreck millions of lives. Why, South Sudan was a US project, aimed at breaking up and weakening Arab Sudan. Sudan's dictator, Omar al-Bashir, is in the Washington dog house as Bad Dictator. Kiir Mayardit isn't brought up. The Bad Dictators are arguably Bad, and some are war criminals. But Washington tends to deal with the pro-American dictators by just not bringing them up much, or by stressing their friendliness rather than their rapaciousness when they are brought up.

Those critics, for instance, who have not spent time in the barrios of Venezuela working with Chavista activists, and are bereft of a trusted cadre of revolutionary intellectuals to provide to them a dialectically marinated assessment of what is happening in that country, are likely to have an immediate and negative visceral reaction at the mere mention of the names Hugo Chávez or Nicolás Maduro, which is a symptomatic reaction (a "structure of feeling," to echo Raymond Williams, but perhaps more like a Pavlovian reflex action) to the techno-mediated poison fed to the public by those free-market intellectuals who possess hegemonic ascendency in today's mediaverse.

Free-market intellectuals model language on their specific understanding of the capitalist marketplace. David McNally. (2001) has argued that in the process of such modeling, formal linguistics turns language into the dead labor of fetishistic commodities. The free-market intellectual is unable to undress the dialectical unfolding of capital's logic of abstraction and to lay bare the way it has been internalized and integrated into the labyrinthine dimensions of our everyday consciousness. How is it that the freemarket intellectual so seamlessly suffocates the very categories that provide the conditions of possibility for critical reflexivity? Because free-market intellectuals all too cavalierly decapitate signifiers and their meaning-making process from their fundamental connection to living labor. Linguistic value as a general equivalent of exchange is equated by the free-market intellectual with fictitious capital-with abstract labor that becomes the gold standard against which signs are measured and/or interpreted. If, for instance, we side with Derrida and argue that there is only differance, that unknowable form prior to language, that condition of undecidability and the very condition of possibility of that undecidability that permits the endless play of reference that Derrida famously discusses in his large corpus of work, then differance becomes the most general structure of the economy. The economy becomes simply the signifier money circulating in the graveyard of labor, independent of any external referents, ensepulchered in its own prison house of self-referentiality, never able to transcend the codes that define it and give it life. And in doing so, Derrida, and other postmodern doyens of the metropole, manage to obscure both the genuine public issues and the mediation of them through unconscious grammars that deny the praxis and labor that ground economic relations. Hence, for them, there is no escape from this capitalist social universe of living death. And that is because, among other reasons, there is no recognition of the potential role played by labor power (our capacity to labor) as a means to contest the rule of capital. We can, after all, collectively refuse to sell our labor power for a wage! Among free-market 
intellectuals, there is little or no conceptual grasp of the relationship between knowledge and value production. Value is the "very matter and anti-matter of Marx's social universe" (Neary \& Rikowski, 2000, p. 8). We need to be clear in maintaining that the production of value is not the same as the production of wealth. The production of value (monetized wealth) is historically specific and emerges whenever labor assumes its dual character as use value and exchange value. This is most clearly explicated in Marx's discussion of the contradictory nature of the commodity form and the expansive capacity of the commodity known as labor power. In this sense, labor power becomes the supreme commodity, the source of all value. For Marx, the commodity is highly unstable, and nonidentical. Its concrete particularity (use value) is subsumed by its existence as value-in-motion or by what we have come to know as "capital" (value is always in motion because of the increase in capital's productivity that is required to maintain expansion). The most essential ingredient of Marx's dialectical conceptualization is his concept of "internal relations," specifically the dialectical contradiction, or the internally related dialectical nature of capitalism itself. The revolutionary intellectual is about discerning how the value form becomes a form of capture that affects all aspects of life within capitalist societies. This requires a dialectical conceptualization of capital that perceptively uncovers the antagonistic terrain of capital that is inherent in the labor-capital relation itself. The internal relations of capital are rife with dialectical contradictions that affect our dreams, desires, and beliefs wherein life becomes reduced to acquisition, to accumulation, to the winning and holding of power. The revolutionary intellectual reads capital in a way that is consistent with Marx's use of the labor theory of value. In order to understand the relation between civil society (i.e., the public sphere) and the state, the revolutionary intellectual needs both Gramsci and Marx. Fischman and McLaren (2005) explain:

Whereas Gramsci (1971) often stressed as a defining attribute the spirit or the will, Marx gave pride of place to production. Gramsci emphasized human consciousness as a defining attribute of humanity. Consciousness, akin to spirit, was linked to the notion of history as a form of becoming. Organized will becomes the basis of his philosophy. Although Gramsci acknowledges the link between humanity and production, he does not sufficiently emphasize the most important aspect of humanity's "complex of social relations": the satisfaction of human needs and the human necessity to produce... The satisfaction of human needs is the primary historical act and must be accomplished before men and women are in the position to make history. The human necessity to produce and reproduce thus underwrites all social relationships. For Gramsci, humanity is defined by concrete will, will plus historical circumstances, whereas for Marx, humanity is a response to and product of social and historical circumstances that are not primarily dependent on human will. Human relationships thus exist independently of the way in which people understand them.

(pp. 428-429)

Like Gramsci, the revolutionary intellectual associates hegemony with a wide range of institutions that serve as intermediaries between the state and the economy: the church, schools, the press, the family, hospitals, political parties, and so on. However, unlike many leftist scholars who have underestimated Gramsci's attempt to connect these 
institutions associated with civil society to the power of the state, the revolutionary intellectual understands civil society as integral to state power. Hence, the struggle for the revolutionary intellectual is not to transform civil society but rather to build proletarian hegemony (Fischman \& McLaren, 2005). Gramsci's appropriation by postmodernists has too often emphasized the priority of language and representation in the hegemonic processes of identity formation and failed to give sufficient consideration to how the social construction of race, class, and gender is implicated in the international division of labor. In other words, free-market intellectuals have not sufficiently comprehended the importance of understanding and challenging the totalizing power of capitalism. The revolutionary intellectual, according to Fischman and McLaren (2005),

acknowledges the strategic centrality of class struggle in his work. We argue for a counterhegemonic coalition of social formations comprising committed intellectuals whose political bonds are interconnected and articulated through the unification of demands in heterogeneous, multifaceted, yet focalized anticapitalist struggles. This is not to limit counterhegemonic struggles to the productivist framework of unilinear labor struggles or Marxist "workerism," for instance, but rather to forge by means of a unified subaltern historical bloc new bonds between labor and new social movements without dismissing the potential of politically unorganized social sectors, such as the growing numbers of unemployed and homeless... One of the main goals of these diverse coalitions should be to suffocate the authoritarian power of the state and curb its ability to support other structures of oppression. To do so demands moving beyond localized radical struggles and the creation of networks of micropolitical struggles. This does not mean we reject community-based multiform politics, but rather stress the need to coordinate our single-issue and micropolitical efforts so that the power of the state's apparatus is not underestimated and can be effectively challenged. Of course, we also acknowledge that the state is not the all-encompassing and indomitable structure of domination that orthodox Marxists have often claimed, as there exist fault lines than enable challenges from below. But we also recognize that state formations, whereas more fluid in the context of global markets and the internationalization of capital, have not become obsolete. In fact, they are functionally necessary to promote the reproduction of capitalist social relations and their transnational expansion... (pp. 438-439)

Commodification regulates our social lives, and the free-market intellectual plays an important role in the unending process of decapitating theory from practice, and practice from theory, by turning language into a graveyard of dead letters. What this practice mystifies is the fecund possibilities of political struggle through the development of a philosophy of praxis. Choosing to work as a revolutionary intellectual, especially in a university setting, means a commitment to become part of a wider political project that expands-and in some cases sublates-the frozen horizon of the academic world. This is becoming more difficult as the university, having submitted to the constitutive hysteresis of capitalist schooling, remains blinded by its own corporate radiance, and perpetually distracted from its transformative role. One of the most obvious hurdles for the revolutionary intellectual is the entrenched manner in which capitalism has remained such a popular choice among students who remain fettered by argumentum ad populum 
positions that go unchallenged by professors. A dimension of this dilemma is well captured by Antonia Darder (2011) in her description of the dissident educator:

The struggle against oppression for true dissidents is not an individual matter, but rather in concert with a larger political project that informs the transgressions and disruptions of dissent. It is precisely this collective and communal agenda of struggle that makes the ways of dissidents fully unintelligible to both their conservative and liberal peers. This is particularly so within academia, where an allegiance to the working class and anti-imperialist agenda is regarded as vulgar or passé; and where activist scholarship is frowned upon as lacking rigor and dangerously too steeped in practical concerns. Why should an intellectual with a secure position and good pay venture into the danger zones of such unstable terrain? Such are the attitudes that prevail among collegial circles when one not only writes about liberation, but also seeks to embody liberation as a living praxis. Within the university, dissident praxis is generally met with suspicion.

\section{The Revolutionary Intellectual as Philosopher of Praxis}

The revolutionary intellectual is a philosopher of praxis par excellence. Because the revolutionary intellectual focuses on interrogating and transforming the constituent amalgam of the complex and concrete social totality through which all of us live to labor and labor to live in particular historical moments. This is the essence of historical materialist critique, a practice that is designed to give momentum to a revolutionary praxis designed to challenge those asymmetries of power and privilege carefully calibrated to meet capital's abiding concerns.

Revolutionary intellectuals not only uproot the assigned meanings of terms such as friend/enemy or dictator/liberator as they have contributed to the semantic gestation of modernity and as they operate today in the social imaginary and class habitus of the population, but also recalibrate them as conceptual domains in need of rearticulation and regeneration. In so doing revolutionary intellectuals challenge the hegemonized narrative spaces in which these terms are frequently debated and discussed. This is accomplished both by giving visibility to subaltern analytic spaces of contestation and non-Western systems of intelligibility and by foregrounding new forms of protagonistic agency. These new forms of protagonistic agency expend their critical energies in a radical transformative critique of oligopolistic corporate power, shattering the dependent hierarchies behind which all metropolitan free-market critics hide (e.g., capitalism, white privilege, heteronormativity, ableism, ageism, patriarchy), marking such hierarchies as fetid spaces of political retrogression where externally imposed and therefore stereotypically limited identity formations predominate and are firmly attached to the acrimonious, predominantly aggressive, and infantile emotional impulses, reminiscent 
of talk-radio "shock jocks," of the Twitter-obsessed president of the most powerful country in the world. By assisting us in our critique of the bountiful dung heap of capitalism's contradictions and the ideological apparatuses of the integral state, the revolutionary intellectual helps us to discover the freedom in our actions as socially affirmed selves, in new sets of actions that can lead to more actions, actions that can bend the bars of the prison house of capitalist accumulation and secure our release from the comfortable grasp of mystification that encourages us to accept the chains that bind us without ever being aware of what creates them.

The revolutionary intellectual helps us to acquire competence in understanding how our chains are forged through hegemonic apparatuses of public control and technocratic social engineering practices and to find our truth in our actions, in our lived praxis. And she helps us to affirm that the truth of our ideas exists only in practice. This is a revelation that finds its most perfect embodiment in Marx's final, definitive thesis on Feuerbach: "The philosophers have only interpreted the world in different ways; the point, however, is to change it." The revolutionary intellectual serves as an interpretive crucible in a material regrounding of cultural critique, pressing our languages of analysis to undergo the evolution necessary for the creation of new knowledges through a critical elaboration of the power/knowledge complex, whereby we would be able, for instance, to gain a deeper recognition of the ways and means provided to White people to secure their humanization and security at the price of Black and Brown dehumanization and their molecular absorption into the dominant rhetorics of White culture.

This suggests that what is needed is an indigenization of the revolutionary intellectual that embraces forms of critique mediated by subalternists and third world intellectuals (San Juan, 2013). The revolutionary intellectual is a border crosser who invites us to participate in the creation of new understandings within the evangelized social core of the culture where the language of capitalism is spoken in tongues, and within the broader constituencies of empire where the only language respected is that of militarized violence. The revolutionary intellectual possesses a capacity to abstract within a framework of levels of generality that can produce different levels of analysis and critique necessary to explain the differential practices and outcomes that are endemic to living in a world riven with capitalist social relations and alienated self-esteem. The revolutionary intellectual underscores the necessity of employing a dialectical methodology, paying attention to internal relationships among contradictions, as well as interfacing local subaltern practices with the concrete universal of anti-imperialist liberation (San Juan, 2013). This stipulates an attentive focus on the structural features of capitalist accumulation while at the same time registering a critical assessment of the unfolding of everyday life and its shifting localities and diverse inflections, mapping the emergent movement and development of the material reality of capitalism - that is, the myriad roles and registers in which capital constitutes our lived subjectivity and the material constraints against which it is formed. In short, the revolutionary intellectual undertakes a reciprocal reading of everyday life that is neither reductive nor teleological nor one that occupies an historical space of irreversible dread, yet at the same time forcefully challenges capitalism's dialectic of self-preservation. 
Capitalism is a problem of exploitation, but we must not forget that it is also a logic of abstraction (Hudis, 2012). In other words, it is congealed value-creating labor, and this makes capital, as a social form, alienating since it dominates concrete living labor by abstract dead labor, and this is true whether it involves state control or market anarchy. Consolidating proletarian culture, as some revolutionary intellectuals advise as an antidote to our imbrication in the discourse of colonialism and globalized capitalism, including and peripheral spheres of structural inequality is, in our view, still narrowcasting our vision, since who wants a repeat of the totalitarian socialism that marked the 2oth century? Such a move make be important, but it is not the final answer to transcending capital since transcending capital, according to Marx, requires the self-abolition of the proletariat as a political class. Revolutionary intellectuals such as Peter Hudis (2012) maintain that uprooting capital from within the social order through the self-activity of the proletariat and other social forces that seek to negate the value form of mediation marks just the beginning point of the struggle against alienation and exploitation. And no amount of state-imposed "planning" from above will accomplish this task alone. Criticism must always precede solidarity. Proletarian resistance in fact marks not the potential negation of capital but its "fullest realization." If capital negates everything opposed to it, how, then, do we escape its alienating and totalizing horizon if we can't transcend capital internally? Revolutionary intellectuals can help us answer these questions. As we move forward in our struggle, we need to remind ourselves that spontaneous forms of resistance alone remain as insufficient in articulating a viable alternative to capitalist value production and the meta-racism embedded in our technocratic society as does state planning from above, as long as they both remain detached from a dialectical philosophy of praxis and removed from an unraveling of the telos of the commodity form. Unless this remains a precondition for building a new society, the likelihood remains for a recuperation of the very systems of domination that one is attempting to eradicate. This is the way that revolutions can turn into their opposite.

Our way out of this conundrum is by becoming philosophers of praxis. This stipulates that we never remain impervious to our critics, and that we participate in the revolutionary process by listening to and learning from revolutionary intellectuals such as Paulo Freire (2000), who have taught us to give ontological priority to the voices of the oppressed and who have constantly reminded us that the project of liberation is fundamentally a quest to become more fully human by creating our world through our transforming labor, by participating in the untested feasibility that lies beyond the limit-situation of the existential moment, so that we can emerge from the plentitude of revolutionary praxis not simply "feeling" our needs but struggling to comprehend their causes and the means to transform them. The revolutionary intellectual's project remains in consonance with the goal of decolonization but is also committed to the concrete universal of emancipation from capitalism and its state apparatuses. Emancipation is not some one-time transaction from below, nor is it a singular self-generating feat. Every mobilization against injustice serves as a collective tipping point, a chance to build a surfeit of conviction in the justness of our cause, an opportunity to reaffirm our collective goal that is neither a guarantee nor a blueprint. 
Lastly, the revolutionary intellectual needs to ask: What different type of social universe-one that reflects freely associated labor and non-alienating human relationsis implied in the suffering of the masses? This remains the challenge for today's revolutionary intellectuals. It is a question that cannot be answered once and forever. Yet only by incorporating an understanding of what a viable alternative to capital could look like can our struggle for social justice be responsible to history.

\section{REFERENCES}

Allman, P. (1999). Revolutionary social transformation: Democratic hopes, political possibilities and critical education. Westport, CT, and London, UK: Bergin and Garvey.

Boardman, W. (2017, April 18). In Afghanistan: America's longest war will never be won, Reader Supported News. Retrieved from http://readersupportednews.org/opinion2/277-75 /43102-focus-in-afghanistan-americas-longest-war-will-never-be-won

Cole, J. (2017, May 2). Trump's real sin in DC is not distinguishing between "good" and "bad" dictators. Reader Supported News. Retrieved from http://readersupportednews.org/ opinion 2/277-75/43349-focus-trumps-real-sin-in-dc-is-not-distinguishing-betweenqgoodq-and-qbadq-dictators

Collins, K. (2017, April 12). Fox business host corrects Trump when he says he fired missiles at Iraq. Daily Caller. Retrieved from http://dailycaller.com/2017/04/12/fox-business-hostcorrects-trump-when-he-says-he-fired-missiles-at-iraq/

Darder, A. (2011, April 10). The making of a postcolonial dissident scholar. Presentation at the Postcolonial Studies in Education SIG meeting, American Educational Research Association Annual Meeting, New Orleans, LA.

Darder, A. (2012). Neoliberalism in the academic borderlands: An on-going struggle for equality and human rights. Educational Studies, 48, 412-426.

Evans, S. (2007, Fall). Women of color in American higher education. Thought \& Action, 131-138. Retrieved from https://www.nea.org/assets/docs/TAA_07_13.pdf

Fischman, G. E., \& McLaren, P. (2005). Rethinking critical pedagogy and the Gramscian and Freirean legacies: From organic to committed intellectuals or critical pedagogy, commitment, and praxis. Cultural Studies $\leftrightarrow$ Critical Methodologies, 5(4), 425-447.

Freire, P. (2000). Pedagogy of the oppressed. New York, NY: Continuum.

Girard, R. (1979). Violence and the sacred. Trans. Patrick Gregory. Baltimore, MD: Johns Hopkins University Press.

Giroux, H. (1988). Teachers as intellectuals. Toward a critical pedagogy of learning. Ganby, MA: Bergin \& Garvey Publishers, Inc.

Giroux, H. (2011). On critical pedagogy. New York, NY: Continuum.

Gramsci, A. (1971). Selections from the prison notebooks. New York, NY: International Publishers Co.

Howard, D. (2017, April 17). The robot scabs are coming to take your jobs. CNN News. Retrieved from http://www.cnn.com/2017/04/15/opinions/the-robot-scabs-are-comingto-take-your-jobs-howard-opinion/

Hudis, P. (2012). Marx's concept of the alternative to capitalism. Chicago, IL: Haymarket Books. Jacoby, R. (2000). The last intellectuals: American culture in the age of academe. New York, NY: Basic Books.

Marx, K. (1867/2011). Capital (vol. I). Mineola, NY: Dover Publications. 
Marx, K. (1870). Letter to Sigfrid Meyer and August Vogt. Letters of Karl Marx 1870. Retrieved from https://www.marxists.org/archive/marx/works/1870/letters/70_04_09.htm

Mayo, P. (2010). Gramsci and educational thought. London, UK: Wiley-Blackwell.

Mayo, P. (2015). Hegemony and education under neoliberalism: Insights from Gramsci. New York, NY: Routledge.

McLaren, P. (2000). Che Guevara, Paulo Freire and the pedagogy of revolution. Lanham, MD: Rowman and Littlefield.

McLaren, P. (2006). Life in schools: An introduction to the social foundations of education. London, UK, and New York, NY: Routledge.

McLaren, P. (2015). Pedagogy of insurrection: From revolution to resurrection. New York, NY: Peter Lang Publishers.

McLaren, P. (2018). Dare we create a new socialist order? A challenge to educators of America in the coming Trump era. In P. McLaren \& S. SooHoo (Eds.), The radical imagine-nation: Public pedagogy and praxis (pp. 85-120). New York, NY: Peter Lang Publishers.

$\mathrm{McNally,} \mathrm{D.} \mathrm{(2001).} \mathrm{Bodies} \mathrm{of} \mathrm{meaning:} \mathrm{Studies} \mathrm{on} \mathrm{language,} \mathrm{labor,} \mathrm{and} \mathrm{liberation.} \mathrm{Albany,} \mathrm{NY:}$ State University of New York Press.

Monzó, L. D. (2014). A critical pedagogy for democracy: Confronting higher education's neoliberal agenda with a critical Latina feminist episteme. Journal for Critical Education Policy Studies, 12(1), 73-100.

Monzó, L. D. (2016). “They don't know anything!”: Latino immigrant children appropriating the oppressor's voice and the complicit role of schooling. Anthropology \& Education Quarterly, 47(2), 148-166.

Monzó, L. D., McLaren, P., \& Rodriguez, A. (2016). Deploying guns to expendable communities: Bloodshed in Mexico, US imperialism and transnational capital-A call for revolutionary critical pedagogy. Cultural Studies $\leftrightarrow$ Critical Methodologies, 17(2), 91-100.

Moran, L. (2017, April 7). Brian Williams uses Leonard Cohen lyric to describe "beautiful" strike on Syria. Huffington Post Retrieved from http://www.huffingtonpost.com/entry/ brian-williams-leonard-cohen-syria_us_58e76c44e4bo58foa02e12b1?5xc\&

Neary, M., \& Rikowski, G. (2000, April). The speed of life: The significance of Karl Marx's concept of socially necessary labor-time. A paper presented at the British Sociological Association Conference 2000, "Making Time/Marking Time," University of York.

Nwanevu, O. (2017, April 12). Donald Trump, our kid president, ordered Syria strike during dessert. The Slatest. Retrieved from http://www.slate.com/blogs/the_slatest/2017/04/12/ donald_trump_our_kid_president_struck_syria_over_chocolate_cake.html

Robinson, W. (2016). Global capitalism and the restructuring of education: The transnational capitalist class' quest to suppress critical thinking. Social Justice, 43(3), 1-24.

Robinson, W. (2017, April 18). Global capitalist crisis and Trump's war drive. Telesur. Retrieved from http://www.telesurtv.net/english/opinion/Global-Capitalist-Crisis-and-Trumps-WarDrive-20170418-0009.html

San Juan, E. (2013). Reflections on academic cultural studies and the problem of indigenization in the Philippines. Topia, 29(Spring), 73-93.

Tankersley, J. (2016, November 9). How Trump won: The revenge of working-class Whites. Washington Post. Retrieved from https://www.washingtonpost.com/news/wonk/wp/2016 $/ 11 / 09 /$ how-trump-won-the-revenge-of-working-class-whites/?utm_term $=.9 e 0 e e 788668 \mathrm{c}$

Thomas, P. (2011). The Gramscian moment: Philosophy, hegemony and Marxism. London, UK, and New York, NY: Haymarket Books. 